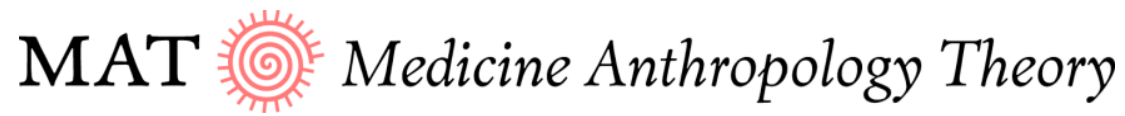 \\ BOOK AND FILM REVIEWS
}

\section{Witchcraft and a life in the new South Africa}

Reviewed by Sjaak van der Geest

Isak Niehaus, Witchcraft and a Life in the New South Africa. Cambridge: Cambridge University Press, 2013. Hardcover, 239 pp., \$99.00, £60.00. ISBN: 9781107016286.

If Isak Niehaus's book had been a novel, I would have told him he had gone too far to make his point. The story of his anti-hero Jimmy Mohale (a fictitious name) would have been convincing enough with half of the deaths, witchcraft accusations, and diviner visits it contains. The overkill makes the reader suspicious: this bit is too much; that part does not sound real. But Niehaus's book is not a novel, it is an ethnography. As he explains in his introduction, his aim is 'to explore how the biography of one South African can inform our understanding of witchcraft in contemporary South Africa' (p. 3). He tries to show how one man 'experienced the broader changes taking place in the country from 1964 to 2005, and came to interpret the misfortunes he encountered and his fatal illness as resulting from his father's witchcraft' (p. 3). By revealing the dramatic end of his protagonist's life at the outset of the book, he creates a level of suspense equal to that of an Agatha Christie thriller.

Jimmy Mohale was the brightest child in a polygamous family with thirteen children, living in the rural northeast of South Africa, in what is now called the Bushbuckridge area. His father was a migrant labourer and rarely at home. The household was mainly run by his father's two wives. 
Niehaus met Jimmy at the age of twenty-seven, in 1990, when he started fieldwork in the area and invited him to become his assistant and co-researcher. That relationship developed into friendship. So, the book is not only an annotated biography that gives the reader insight into apartheid and post-apartheid South Africa; it also tells the story of an anthropologist and his assistant, which makes the book particularly intriguing, as the position of and the relationship to assistants is an underexposed topic in fieldwork accounts. Exploitation and condoned plagiarism of the work of assistants is probably more common than publicly acknowledged. Moreover, the balance between exploitation and friendship is delicate. Throughout the book, Niehaus candidly writes about his complex relationship with his friend/assistant.

Niehaus lets Jimmy tell his life story, interlaced with his own comments and information regarding the wider context of the events and anthropological and personal reflections. Remarkably, he did not use an audio recorder because Jimmy was opposed to it. The telling of Jimmy's entire life story is, amazingly enough, based on notes taken during countless sessions. We are back in Malinowski's era. The result is an extraordinary book that fully achieves its objective. Jimmy is an entertaining storyteller, and his biographer is a perceptive listener and gifted writer. The reader - or at least this one - becomes totally immersed in the events that lead to Jimmy's demise.

The chapters relate Jimmy's life in more or less chronological order. Chapter 2 describes his early childhood, with vivid images of family life, schooling, and his first encounters with witchcraft. His memories of school life, with its abundance of physical punishment and teacher terror, are particularly revealing. The next chapter, 'Becoming a Man', relates among other things his circumcision experiences, his marriage, his further education and first employment as a teacher, and his reluctance to get involved in politics. Chapter 4 recounts a large number of deaths in Jimmy's family and the subsequent rumours that began to spread about his father's witchcraft. Initially, Jimmy rejects the accusations and defends his father, but three years later he becomes his father's fiercest accuser. This turn happens during an intensely painful period of his life, which he calls 'My Second Initiation', a phrase which points to 'his predicament in adult life' and not at 'the opening up of new vistas' (p. 95). His car breaks down, and his marriage as well. His teaching career comes to a halt, and he feels rejected and misjudged by his superiors and colleagues. He loses his home and becomes deeply frustrated. New deaths and his own deteriorating health contribute to his growing involvement in witchcraft accusations and visits to witch doctors and fortune-tellers. An attempt to jump on the political bandwagon does not help him to reverse his decline.

The seventh chapter, 'Seeking Revenge', brings the climax of Jimmy's paranoia about his father's destructive power. Together with his brothers, he rushes from one diviner to 
another to find protection against his father and to look for magic and potions with which to kill him. Witch doctors seem to have free rein to confirm and thus intensify witchcraft accusations and anxiety in the new South Africa, contributing to widespread insecurity and violence, all the while promising the opposite. All of Jimmy's attempts fail, and result, finally, in the devastation of his getting AIDS. Jimmy refuses to be tested for the disease or take the new medicines, although the symptoms are undeniable. He maintains that no doctor can help him against his father's destructive power. He is not the only one; the author reports in a footnote that by 2006, 80 percent of South Africans in need of antiretroviral drugs were not receiving them (p. 161).

Niehaus is unable to change his friend's decision. He gives Jimmy money to consult a medical doctor, but it is used for yet another witch doctor. Niehaus realises in retrospect that he made a serious mistake in 'not being more confrontational' (p. 176). But, speaking as an anthropologist, he understands that the witchcraft accusation was more attractive to Jimmy: '[it] excused him from blame and ... created the possibility of revenge against his father' ( $p$. 176). Niehaus describes the dilemma of being both a researcher and a friend as follows: 'Despite our very intimate social ties, I could not share the conviction of witchcraft that united Jimmy and his siblings. My suspicion of AIDS seemed to have confirmed my status as perennial outsider' (p. 182).

Jimmy's funeral is a choreography of lies and pretence. Nearly two thousand people attend the church service, the expensive coffin arrives in a Mercedes-Benz, nineteen speakers including the author - extol Jimmy's virtues and talents, calling him a '[h]ighly successful professional, a member of a stable middle class, and an exemplary colleague, kinsman, affine, husband and father' (p. 196), among many other tributes. Niehaus concludes: 'Jimmy received in death the wealth and harmony he could never attain in life' (p. 197).

I could not resist retelling Jimmy's story as presented by his friend and anthropologist, because the story is the heart of Niehaus's analysis of life in the new South Africa - a vibrant but highly depressing kind of life. The story is so powerful and convincing that the concluding chapter, 'Last Words' (not Jimmy's but the author's), where Niehaus reverts to anthropological concepts and debates, feels redundant and out of place. They seem to neutralise and refute the tragic powerlessness of both Jimmy and the anthropologist to reverse the course of events. Concluding this tale of failure and destruction with an anthropological reflection rather underlines the author's success in having produced an excellent but also painful anthropological monograph. We cannot deny it: other people's misery is the food of our profession. Friendship cannot stop us. But I prefer to end my 'review' in another tone: Niehaus's book offers a pungent and tragic picture of present-day South Africa and a tribute to a dear friend who fell victim to it. 


\section{About the author}

Sjaak van der Geest is Professor Emeritus of Medical Anthropology at the University of Amsterdam, the Netherlands. He did fieldwork in Ghana and Cameroon and published on a wide range of topics, including perceptions and practices concerning birth control, witchcraft beliefs, Ghanaian Highlife songs, missionaries and anthropologists, anthropology of the night, and various topics in medical anthropology, in particular the cultural context of Western pharmaceuticals in non-Western communities, hospital ethnography, perceptions of sanitation and waste management, and social and cultural meanings of growing old. Personal website: www.sjaakvandergeest.nl. 